\title{
Kemampuan Kognitif Anak Usia Dini Dalam Pembelajaran Akuatik
}

\author{
Lutfi Nur, Anne Hafina, Nandang Rusmana \\ lutfinur@upi.edu, annehafina@upi.edu,nandangrusmana@upi.edu \\ Universitas Pendidikan Indonesia
}

The Cognitive Ability Of Early Childhood In Aquatic Learning

\begin{abstract}
The purpose of this article was to describe the cognitive abilities of early childhood in aquatic learning. This research uses a descriptive method. The subjects in this study were ten students of grade B children aged 5-6 years. The instrument in this study uses structured observation and field notes about children's cognitive ability which include class procedures, pool rules, playing rules, instruction language, and movement mechanics. The data analysis technique used is descriptive statistics. The results showed that the cognitive ability of children aged 5-6 years in the Pilot Laboratory of UPI Campus Tasikmalaya was still in the Start Developing category. This can be seen from the findings in the Tasikmalaya UPI Pilot Laboratory Kindergarten that the score of children's cognitive abilities was $44 \%$.
\end{abstract}

Keywords: Cognitive Ability, Aquatic Learning, Early Childhood

Received date: 7 Juli 2019

\section{Article Info}

Revised date: 17 Januari 2020

Accepted date: 22 Januari 2020

\section{PENDAHULUAN}

Pendidikan anak usia dini (PAUD) adalah sebuah program pembinaan yang dilakukan pada anak usia 0 sampai 6 tahun agar anak memiliki kesiapan pada pendidikan selanjutnya (Rindaningsih, 2012). Fokus pengembangan PAUD terhadap anak usia dini diantaranya adalah aspek kognitif dan fisikmotorik. Lingkup perkembangan kognitif terdiri dari belajar dan pemecahan masalah, berpikir logis, dan berpikir simbolik. Sedangkan perkembangan fisik-motorik yaitu kesehatan dan keselamatan, motorik kasar, dan motorik halus.

Dalam upaya mengembangkan seluruh potensi anak diperlukan penanganan yang baik dari berbagai komponen, antara lain dari guru yang merancang proses pembelajaran serta lingkungannya. Geldard \& Geldard (2012) mengungkapkan bahwa faktor lingkungan meberikan pengaruh terbesar dalam perubahan perilaku setiap anak. Artinya lingkungan sekolah merupakan bagian yang amat penting untuk mendidik dan mengembangkan potensi anak. Hasil studi awal penelitian yang dilakukan Hidayat \& Nur, (2018); Nur, Mulyana \& Perdana, (2017) menyebutkan proses pembelajaran yang dilakukan pada Taman Kanak-kanak belum berjalan secara optimal dalam mengembangkan potensi anak. Penyebabnya antara lain kurangnya pemahaman guru dalam pemilihan dan penerapan metode pembelajaran yang variatif serta karakteristik siswa yang beragam.

Ketika kegiatan pembelajaran, para guru masih terjebak pada penerapan-penerapan proses ajar konvensional artinya para guru hanya mengulang-ulang rutinitas aktivitas belajar mulai dari awal pembelajaran, berbaris, menyanyi dan masuk ke dalam kelas. Berdasarkan pengamatan, penerapan proses belajar yang variatif dan inovatif masih jarang dilakukan. Padahal sudah cukup banyak metodemetode pembelajaran yang diterapkan pada anak dalam upaya meningkatkan perkembangan anak usia dini (Hafina, Nur \& Rusmana, 2019).

Adapun metode pembelajaran tersebut antara lain adalah permainan tradisional kaulinan barudak, permainan bola kecil serta pembelajaran gerak dan lagu. Melalui penerapan metode tersebut, terdapat peningkatan perkembangan sikap empati, pola gerak dasar, motorik kasar, dan kecerdasan kinestetik pada anak (Nur, Halimah \& Nurzaman, 2017; Nur, Mulyana \& Perdana, 2017; Respati, Nur \& Rahman, 2018). Namun, penelitian yang menerapkan aktivitas pembelajaran di air (akuatik) untuk mengembangkan kemampuan kognitif masih terbatas. Padahal pembelajaran akuatik bagi anak usia dini dapat memberikan banyak manfaat terhadap perkembangan potensi mereka. Program akuatik prasekolah di negara maju sudah diterapkan sejak lama dengan fokus output pada pengenalan air 
sebagai dasar perkembangan anak serta keterampilan dasar berenang (Alaniz, dkk., 2017). Program pembelajaran akuatik pada anak prasekolah bertujuan untuk memberikan anak pengalaman terhadap aktivitas akuatik yang menyenangkan, berani beraktivitas dalam air, sehingga menstimulus pada perkembangan kognitif, sosial dan motorik anak (Langendorfer \& Bruya, 1995, 2009; Susanto, 2009; Pan, 2010; Sari, 2014; Rocha, dkk., 2018).

Berdasarkan kajian latar belakang, maka tujuan penelitian yang akan dilakukan adalah mengenai penerapan model pembelajaran akuatik berbasis permainan dalam mengembangkan kemampuan kognitif anak usia dini. Namun pada artikel ini akan ditampilkan dahulu hasil studi profil awal kemampuan kognitif anak usia dini. Hasil penelitian penerapan model pembelajaran akuatik berbasis permainan dalam mengembangkan kemampuan kognitif anak usia dini secara keseluruhan akan peneliti sampaikan pada artikel berikutnya.

\section{KAJIAN PUSTAKA}

Anak usia dini merupakan individu yang mempunyai potensi perkembangan dan pertumbuhan yang pesat dalam kehidupannya (Sujiono, 2009; Yusuf, 2012; Hafina, Nur \& Rusmana, 2019). Seringkali anak usia dini disebut fase usia emas. Masa usia emas adalah masa ketika seseorang individu dapat menerima dan mengolah informasi secara cepat dan tahan lama (Hurlock, 1980; Santrock, 2007, Nurihsan \& Agustin, 2011; Yusuf, 2012). Dalam rangka mengembangkan potensi anak usia dini diperlukanlah sebuah lembaga pendidikan Pendidikan Anak Usia Dini (PAUD). PAUD bertujuan untuk membina anak sejak lahir sampai usia 6 (enam) tahun dengan memberikan rancangan pendidikan untuk membantu pertumbuhan dan perkembangan jasmani dan rohani agar anak memiliki kesiapan dalam memasuki pendidikan selanjutnya (Permendikbud No. 137 Tahun 2014). Lebih lanjut PAUD merupakan salah satu bentuk penyelenggaraan pendidikan yang meliputi integrasi dari perkembangan aspek nilai agama dan moral, fisik motorik, kognitif, bahasa, sosial emosional dan seni (Hasanah, 2016; Rahma, 2017).

Sujiono (2009) mengungkapkan tujuan pendidikan pada anak usia dini adalah mengembangkan pemahaman dan pengetahuan orang tua, guru, dan pihak terkait dengan pendidikan dan perkembangan anak usia dini. Secara khusus tujuannya yaitu: (1) dapat mengidentifikasi perkembangan fisiologis pada anak usia dini dan memperoleh hasil identifikasi dalam pengembangan fisiologis anak; (2) dapat memahami perkembangan kreativitas anak pada usia dini dan usaha-usaha yang terkait dengan upaya pengembangannya; (3) dapat memahami kecerdasan jamak dan kaitannya dengan perkembangan anak usia dini; (4) dapat memahami arti bermain bagi perkembangan anak pada usia dini; dan (5) dapat memahami model pembelajaran dan pengaplikasiannya pada pengembangan anak di usia dini.

Urgensi pendidikan anak pada usia dini berdasarkan tinjauan psikologi adalah mengembangkan berbagai aspek kecerdasan yang merupakan bawaan. Rakhmat, Budiman, \& Herawati (2008) menyatakan beberapa hal antara lain bahwa faktor keturunan mempengaruhi perkembangan seseorang, seseorang ditentukan oleh faktor lingkungan, dan perkembangan seseorang dipengaruhi oleh kedua faktor di atas, yaitu faktor bawaan dan faktor lingkungan. Potensi yang dimiliki anak sejak lahir akan berkembang ketika dibesarkan dalam lingkungan yang mendukung. Sebaliknya, bagaimanapun besarnya potensi seseorang, tidak akan berarti apa-apa bila tidak dikembangkan dalam lingkungan yang baik. Hal ini diperkuat oleh Van De Waal \& Henriette (1993) mengatakan bahwa 90\% faktor hereditas mempengaruhi kondisi fisik anak, sementara kondisi lingkungan keluarga mempengaruhi keterampilan fisik anak.

Perkembangan kognitif anak usia dini meliputi: 1) belajar dan pemecahan masalah, mencakup kemampuan memecahkan masalah sederhana dalam kehidupan sehari-hari dengan cara fleksibel dan diterima sosial serta menerapkan pengetahuan atau pengalaman dalam konteks yang baru; 2) berpikir logis, mencakup berbagai perbedaan, klasifikasi, pola, berinisiatif, berencana,dan mengenal sebabakibat; dan 3) berpikir simbolik, mencakup kemampuan mengenal, menyebutkan, dan menggunakan konsep bilangan, mengenal huruf, serta mampu merepresentasikan berbagai benda dan imajinasinya dalam bentuk gambar (Permendikbud No. 137 Tahun 2014). Agar pencapaian perkembangan anak dapat optimal, dibutuhkan keterlibatan orang tua, dan akses layanan PAUD yang bermutu. Dalam tahap perkembangan kognitif, anak usia dini 0-6 tahun masuk pada tahap sensori motor dan pra operasional (Rahman, 2009). 
Tahap sensori motor, aktivitas kognitif terpusat pada aspek alat dria (sensori) dan gerak (motor), artinya anak hanya mampu melakukan pengenalan lingkungan dengan alat drianya dan pergerakannya. Keadaan ini merupakan dasar bagi perkembangan kognitif selanjutnya, aktivitas sensori motor terbentuk melalui proses penyesuaian struktur fisik sebagai hasil dari interaksi dengan lingkungan. Sedangkan tahap pra-operasional, anak telah menunjukkan aktivitas kognitif dalam menghadapi berbagai hal di luar dirinya. Anak sudah dapat memahami realitas di lingkungan dengan menggunakan tanda-tanda dan simbol (Sujiono, 2009; Ibda, 2015). Permainan di sekitar lingkungan anak (penggunaan gerakan simbolik) memiliki hubungan kuat dengan peningkatan perkembangan kognitif (Barnett \& Kleiber, 1982; Faber, 2017). Artinya, penerapan senam fantasi diduga dapat berkontribusi terhadap peningkatan perkembangan kognitif anak.

Menurut Sismadiyanto (2006) akuatik ialah segala macam bentuk kegiatan dalam air yang dapat dilakukan di sungai, danau, laut, pantai, maupun kolam renang. Program akuatik untuk prasekolah identiknya dengan kegiatan di kolam renang. Program akuatik merupakan segala aktivitas air yang berfungsi untuk mengembankan potensi anak (Susanto, 2014). Lebih lanjut, Nur, dkk (2019) mengungkapkan pembelajaran akuatik bagi anak usia dini lebih difokuskan pada aktivitas bermain yang menyenangkan dan melatih kemampuan anak beradaptasi di air. Indikator keberhasilan akuatik pada anak usia dini terletak pada beberapa indikator keterampilan yang dikuasi, bukan dari jarak jelajah anak ketika berenang. Langendorfer (1995) menyebutkan indikator pemahaman dasar (kognitif) dalam pembelajaran akuatik antara lain: (1) prosedur kelas, (2) aturan kolam renang, (3) aturan bermain, (4) bahasa intruksi, dan (5) mekanika gerakan.

Proses pembelajaran akuatik erat kaitannya dengan prinsip psikologis. Susanto (2012) menjelaskan prinsip-prinsip psikologis yang harus dikembangkan terhadap diri anak dalam mengikuti pembelajaran akuatik agar penguasaan lebih efektif dan efisien diantaranya adalah memupuk rasa senang, keberanian, meningkatkan rasa percaya diri, dan meningkatkan ketekunan belajar. lebih lanjut, proses pembelajaran merupakan bentuk usaha yang dilakukan untuk memperbaiki kualitas pembelajaran guna mencapai tujuan yang diharapkan (Susanto, 2012). Pembelajaran dipandang sebagai sebuah penyediaan lingkungan terencana untuk aktivitas belajar anak, maka keberhasilan penyediaan lingkungan merupakan faktor kunci dalam mendapatkan perilaku dan perubahan belajar yang diharapkan pada anak. Pembelajaran untuk anak usia dini berbeda dengan pembelajaran yang diselenggarakan di jenjang sekolah dasar. Rochmah (2012) menyebutkan bahwa pembelajaran bagi anak usia dini bukan berorientasi pada sisi akademis saja melainkan menitikberatkan kepada peletakan dasar ke arah pertumbuhan dan perkembangan fisik, bahasa, intelektual, sosial-emosi serta seluruh kecerdasan (kecerdasan jamak). Dengan demikian, pendidikan anak usia dini yang diselenggarakan harus dapat mengakomodasi semua aspek pekembangan anak dalam suasana yang menyenangkan dan menimbulkan minat anak.

Program aktivitas akuatik di tingkat prasekolah masih belum optimal, rencana program pembelajaran umumnya belum ada, serta tugas pembelajaran akuatik masih dibebankan pada guru kelas bukan guru dengan keahlian renang (Hafina, Nur \& Rusmana, 2019). Selain itu, program akuatik yang dilakukan masih terjebak dalam tujuan rekreatif semata (Susanto, 2014). Hal lainnya bahwa program renang disusun sesuai dengan standar renang bagi orang dewasa dengan tujuan penguasaan gerakan yang komprehensif sehingga tidak sesuai dengan model pembelajaran yang digariskan dalam kurikulum yang menitikberatkan pada permainan air (water games). Lebih lanjut, bahwa konsep belajar di pendidikan anak usia dini harus berorientasi pada istilah "bermain sambil belajar dan belajar seraya bermain”. Maka, model/metode yang digunakan diarahkan pada aktivitas fisik yang dalam suasana yang menyenangkan, bereksplorasi dan menemukan sesuatu yang baik (Susanto, 2014). Penelitian ini akan mencoba menerapkan pembelajaran akuatik berbasis permainan yang didasarkan pada konsep belajar dalam pendidikan anak usia dini. Hal ini sejalan dengan Susilowati (2014) menjelaskan kekhasan belajar atau modus belajar utama yang umumnya disukai anak usia ini adalah melalui aktivitas langsung (pembelajaran akuatik) dan berbagai situasi yang bertautan dengan minat dan pengalamannya yang umumnya disukai anak usia dini (sesuatu hal baru).

Permainan air adalah metode pengenalan anak terhadap air dengan tanpa disadari. Dengan metode bermain, anak tidak akan terasa bahwa mereka sedang belajar dan tanpa sadar anak telah mengenal sifat air, dan melakukan berbagai gerakan di air. Dengan permainan ini perasaan takut terhadap air diharapkan akan hilang dan timbulah kepercayaan terhadap diri sendiri, sehingga akan mudah kedepannya menerima bentuk-bentuk pelajaran lainnya. Adapun beberapa jenis permainan di 
air antara lain lomba lari dengan menggendong, permainan hitam-hijau, permainan kucing air dan ikan, permainan mengambil uang, permainan menghalau racun, permainan menjala ikan, permainan kartun alphabet, dan sebagainya (Susanto, 2014).

Hafina, Nur \& Rusmana (2019) mengungkapkan bahwa permainan air dapat menjadi cara yang bagus bagi anak untuk terlibat dalam aktivitas fisik, memberikan kesempatan anak untuk menjadi kreatif, dan melatih kepekaan pengamatan terhadap kegiatan sekitar. Selanjutnya Sari (2014) menguatkan bahwa bermain air memberikan manfaat pada aspek sosial anak disamping itu belajar permainan baru juga dapat mengembangkan keterampilan mendengarkan dan perkembangan kognitif. Permainan juga menyediakan lingkungan yang mendukung untuk membantu anak-anak, bahkan yang pemalu, meningkatkan keterampilan interpersonal mereka. Berhasil berinteraksi dengan orang lain membantu mereka memperoleh kepercayaan diri.

\section{METODE PENELITIAN}

Metode yang digunakan dalam penelitian ini adalah metode deskriptif. Partisipan dalam penelitian ini adalah siswa di TK Laboratorium Percontohan UPI Kampus Tasikmalaya dengan usia 56 tahun. Jumlah partisipan dalam penelitian ini sebanyak 10 anak. Instrumen yang digunakan dalam penelitian ini yaitu observasi terstruktur, catatan lapangan dan dokumentasi mengenai kemampuan kognitif anak dalam pembelajaran akuatik yang meliputi prosedur kelas, aturan kolam renang, aturan bermain, bahasa intruksi, dan mekanika gerakan. Teknik analisis data yang digunakan pada penelitian ini adalah statistik deskriptif.

\section{HASIL PENELITIAN DAN PEMBAHASAN}

\section{Hasil Penelitian}

Penelitian ini memberikan gambaran mengenai suatu fenomena tertentu yaitu kemampuan kognitif anak usia 5-6 tahun dalam pembelajaran akuatik. Berdasarkan pengambilan data yang dilakukan, perolehan data kemampuan kognitif anak usia 5-6 tahun di TK Laboratorium Percontohan UPI Kampus Tasikmalaya ketika mengikuti pembelajaran akuatik adalah sebagai berikut:

Tabel 1. Deskripsi Data Total Nilai Pengamatan Kemampuan Kognitif

\begin{tabular}{ll}
\hline Jumlah & 22 \\
\hline Rata-rata & 2.2 \\
\hline Standar Deviasi & 1.23 \\
\hline Skor Maksimal & 4 \\
\hline Skor Minimal & 1 \\
\hline
\end{tabular}

Tabel 1 menunjukkan deskripsi data total nilai pengamatan kemampuan kognitif anak usia dini dalam pembelajaran aquatik. Skor total yang diperoleh untuk keseluruhan aspek yakni sebesar 22, dengan rata-rata skor sebesar 2.2, standar deviasi sebesar 1.13, skor maksimal 4, dan skor minimal 1. Adapun Langendorfer \& Bruya (dalam Susanto, 2014) membuat 5 aspek penilaian yang diperlukan untuk mengetahui kemampuan kognitif anak pada usia dini. Berikut merupakan tabel kemampuan kognitif dalam pembelajaran akuatik prasekolah.

Tabel 2. Aspek Penilaian Kemampuan Kognitif dalam Pembelajaran Akuatik (Susanto, 2014)

\begin{tabular}{cll}
\hline No & Aspek Penilaian & $(\sqrt{ })$ \\
\hline 1 & Prosedur kelas \\
\hline 2 & Aturan kolam renang \\
\hline 3 & Aturan bermain \\
\hline 4 & Bahasa intruksi \\
\hline 5 & Mekanika gerakan \\
\hline
\end{tabular}

Pada Tabel 2 terlihat aspek penilaian kemampuan kognitif dalam pembelajaran akuatik untuk anak usia 5-6 tahun. Aspek penelitian kemampuan kognitif tersebut meliputi: 1). prosedur kelas, 2). aturan kolam renang, 3). aturan bermain, 4). bahasa instruksi, 5). mekanika gerakan. Seluruh subjek penelitian yang berjumlah 10 anak kemudian diamati dengan mengacu kepada aspek penilian 
Kemampuan Kognitif Anak Usia Dini Dalam Pembelajaran Akuatik

(Anne Hafina, Lutfi Nur, Nandang Rusmana)

kemampuan kognitif tersebut. Adapun persentase hasil pengamatan kemampuan kognitif anak terlihat pada gambar 1.

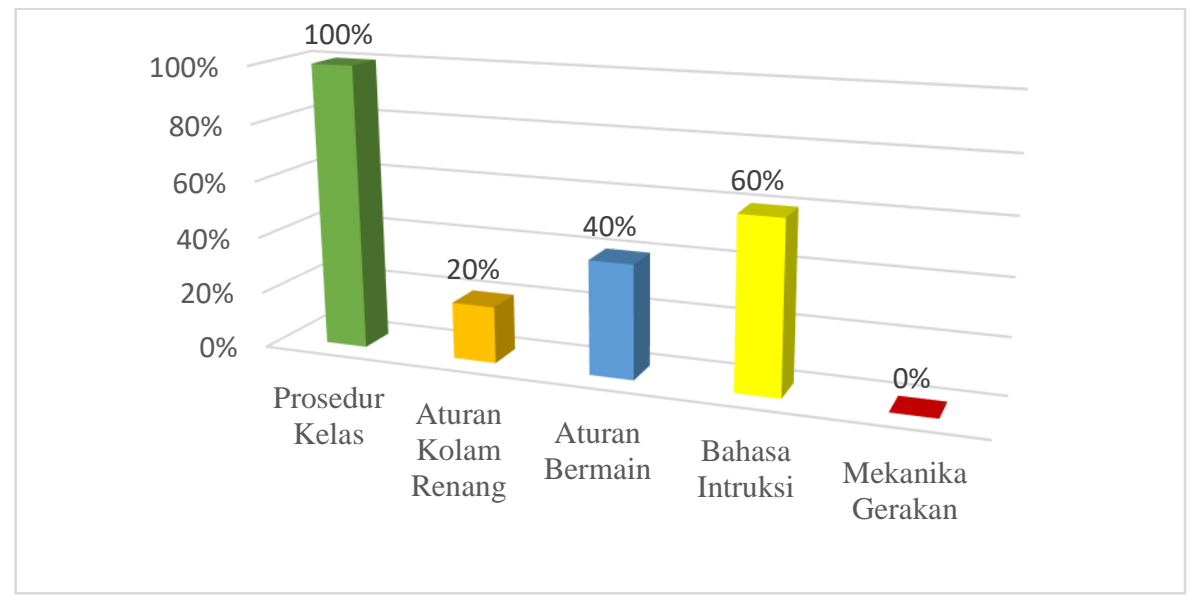

Gambar 1. Grafik Perolehan Skor Berdasarkan Aspek Penilaian

Dari gambar 1 dapat dilihat bahwa aspek penilaian yang memiliki perolehan skor tertinggi adalah aspek prosedur kelas dengan persentase skor sebesar 100\%. Sedangkan aspek penilaian dengan persentase skor terendah adalah aspek penilaian mekanika gerakan dengan persentase nilai $0 \%$. Untuk memberikan gambaran lebih lanjut, berikut data tersebut ditampilkan dalam bentuk grafik perolehan skor berdasarkan sampel penelitian.

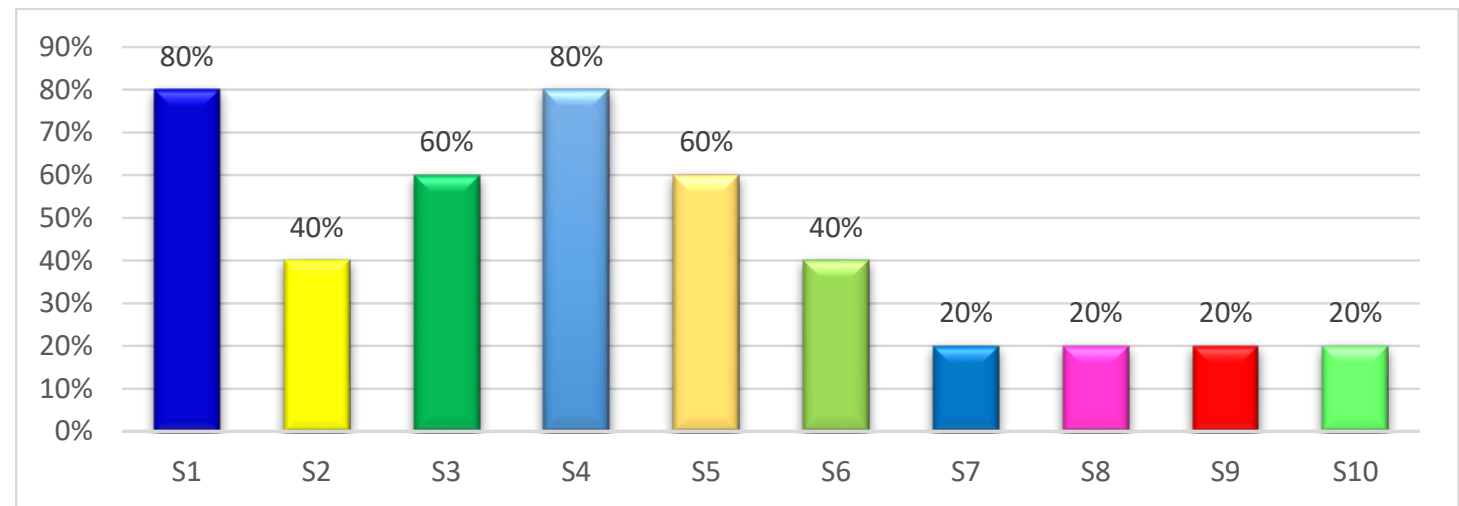

\section{Gambar 2. Grafik Perolehan Skor kemampuan kognitif Berdasarkan Sampel Penelitian}

Grafik pada gambar 2 menunjukkan persentase perolehan skor masing-masing sampel penelitian. Sampel yang memperoleh skor tertinggi adalah sampel S1 dan S4 dengan persentase skor 80\%, skor 60\% diperoleh sampel S3 dan S5, sampel S2 dan S6 memperoleh skor sebesar 40\%, sedangkan sisanya memperoleh skor $20 \%$ yaitu S7, S8, S9, dan S10. Dari data tersebut selanjutnya dapat di konversikan ke dalam kategori sebagai berikut:

Tabel 3. Kategori Pencapaian Skor Berdasarkan Persentase

\begin{tabular}{lc}
\hline \multicolumn{1}{c}{ Kategori } & Rentang Persentase \\
\hline Belum Berkembang (BB) & $0 \%-25 \%$ \\
\hline Mulai Berkembang (MB) & $26 \%-50 \%$ \\
\hline Berkembang Sesuai Harapan (BSH) & $51 \%-75 \%$ \\
\hline Berkembang Sangat Baik (BSB) & $76 \%-100 \%$ \\
\hline
\end{tabular}

Mengacu pada tabel 3, peneliti memberikan kategori penilaian berdasarkan persentase skor yang di capai oleh masing-masing sampel penelitian. lebih jelasnya, hasil penilaian kategori skor sampel perorangan sebagai berikut: 
Scholaria: Jurnal Pendidikan dan Kebudayaan, Vol. 10 No. 1, Januari 2020: 42-50

Tabel 4. Kategori Penilaian Berdasarkan Sampel Perorangan

\begin{tabular}{lll}
\hline Sampel & Persentase Skor & \multicolumn{1}{c}{ Kategori Penilaian } \\
\hline S1 & $80 \%$ & Berkembang Sangat Baik (BSB) \\
\hline S2 & $40 \%$ & Mulai Berkembang (MB) \\
\hline S3 & $60 \%$ & Berkembang Sesuai Harapan (BSH) \\
\hline S4 & $80 \%$ & Berkembang Sangat Baik (BSB) \\
\hline S5 & $60 \%$ & Berkembang Sesuai Harapan (BSH) \\
\hline S6 & $40 \%$ & Mulai Berkembang (MB) \\
\hline S7 & $20 \%$ & Belum Berkembang (BB) \\
\hline S8 & $20 \%$ & Belum Berkembang (BB) \\
\hline S9 & $20 \%$ & Belum Berkembang (BB) \\
\hline S10 & $20 \%$ & Belum Berkembang (BB) \\
\hline
\end{tabular}

Tabel 4 memberikan gambaran kategori penilaian berdasarkan sampel perorangan. pada tabel 4 terlihat bahwa 4 anak masih pada kategori penilaian belum berkembang, sedangkan masing-masing 2 anak pada kategori mulai berkembang, berkembang sesuai harapan, dan berkembang sangat baik.. Secara keseluruhan berikut ini merupakan sebaran skor sampel berdasarkan kategori penilaian.

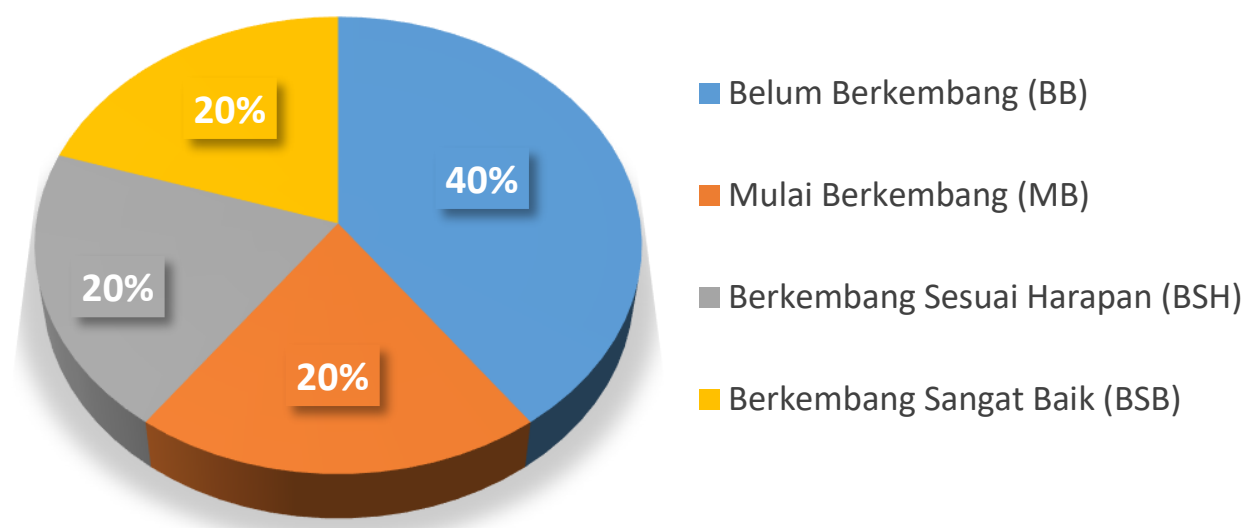

\section{Gambar 3. Presentase Skor Keseluruhan Berdasarkan Kategori Pencapaian}

Dari diagram lingkaran pada gambar 3, dapat diperoleh informasi bahwa $40 \%$ anak mencapai kategori Belum Berkembang (BB), dan sisanya 20\% anak mencapai kategori Mulai Berkembang (MB), Berkembang Sesuai Harapan (BSH), dan Berkembang Sangat Baik (BSB).

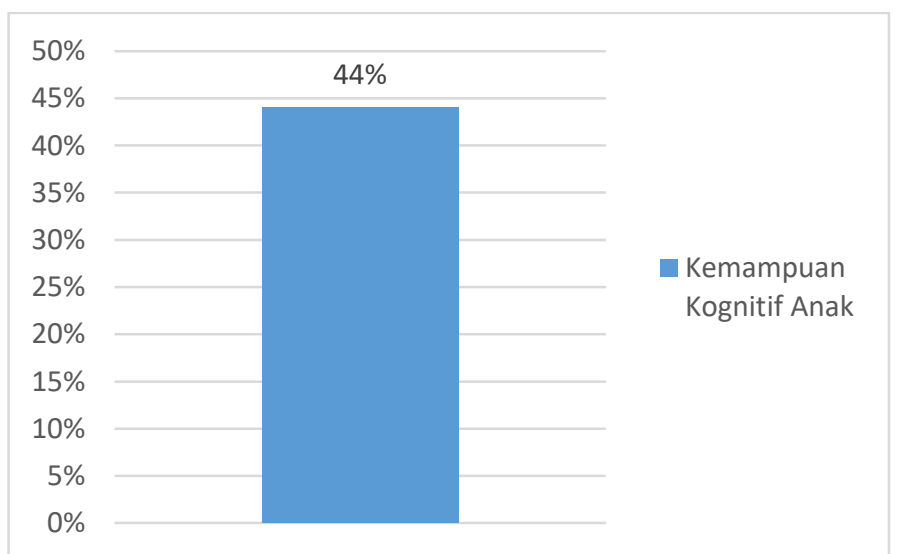

Gambar 4. Presentase Rata-rata Kemampuan Kognitif Anak

Dari diagram batang pada gambar 4, dapat diperoleh informasi bahwa rata-rata kemampuan kognitif anak usia dini sebesar 44\%. Hal ini mempunyai arti bahwa perkembangan kemampuan kognitif anak usia dini dalam pembelajaran akuatik berada dalam kategori mulai berkembang. 


\section{Pembahasan}

Hasil penelitian menunjukkan bahwa kemampuan kognitif anak usia 5-6 tahun di TK Laboratorium Percontohan UPI Kampus Tasikmalaya secara keseluruhan pada persentase 20\% (2 anak) yang masuk kedalam kategori berkembang sangat baik, 20\% (2 anak) yang masuk pada kategori berkembang sesuai harapan, dan 20\% ( 2 anak) pada kategori mulai berkembang. Sedangkan $40 \%$ (4 anak) sisanya pada kategori belum berkembang. Berdasarkan hasil penelitian tersebut menandakan bahwa kemampuan kognitif anak usia dini belum berkembang dengan optimal, sehingga perlu adanya berbagai upaya untuk mengatasi hal tersebut.

Pada intinya, Susanto (2012) menjelaskan bahwa perkembangan kognitif pada anak usia dini (usia prasekolah) berada pada masa preoperasional, artinya anak belum mampu menguasai aktivitas yang dilakukan dengan operasi mental secara logis. Pada periode ini, anak berada pada masa perkembangan "symbolic function", artinya anak mempresentasikan sesuatu dengan menggunakan kata-kata, bahasa gerak (gesture), dan benda (Yusuf, 2012). Lebih lanjut Ibda, (2015) menjelaskan dalam artikelnya yang berjudul perkembangan kognitif: teori Jean Piaget menjelaskan bahwa anak pada masa preoperasional telah menunjukkan aktivitas kognitif dalam memahami realitas di lingkungan dengan menggunakan tanda -tanda dan symbol sehingga cara berpikir anak pada tingkat ini bersifat tidak sistematis, tidak konsisten, dan tidak logis. Oleh karena itu, pemberian pembelajaran akuatik pada anak usia dini harus memperhatikan unsur tersebut sehingga tujuan pembelajaran nantinya dapat tercapai dengan baik.

Salah satu upaya yang dapat ditempuh untuk meningkatkan kemampuan kognitif anak pada usia dini yakni melalui bermain dan permainan. Dunia permainan memang identik dengan anak-anak karena melalui permainan, anak mendapatkan makna belajar yang sesungguhnya (Conatser, 2018). Konsep belajar sambil bermain juga dapat diterapkan pada pembelajaran akuatik sehingga kegiatan pembelajaran menjadi lebih menarik, disamping itu juga dapat dijadikan sebagai wahana rekreasi maupun belajar berkompetisi bagi anak (Langendorfer, 2015). Selain itu, pemberian pembelajaran dengan metode-metode yang inovatif, menarik, dan menyenangkan juga berpengaruh pada pemahaman siswa terhadap materi pembelajaran (Malik, 2013). Perpaduan antara aktivitas berhitung atau mencocokan warna dan gambar dapat menjadi alternatif pilihan dalam pemberian pembelajaran akuatik guna melatih pemahaman kognitif anak.

Berdasarkan penelitian sebelumnya, profil kemampuan awal anak perlu untuk diketahui sebagai landasan guna mengoptimalkan perkembangan anak (Hafina, Nur \& Rusmana, 2019). Dengan adanya data awal tersebut, akan tergambarkan bagian mana saja yang dapat ditingkatkan sehingga hasil profil kemampuan awal kognitif anak ini dapat dijadikan data awal untuk penelitian selanjutnya. Berdasarkan hasil penelitian, teori, dan temuan penelitian terdahulu menunjukkan bahwa capaian hasil kemampuan kognitif anak harus dikembangkan dan ditingkatkan sehingga potensi anak terutama dalam pembelajaran akuatik dapat berjalan dengan optimal.

\section{SIMPULAN DAN SARAN}

Kemampuan kognitif anak usia dini di TK Laboratorium Percontohan UPI Kampus Tasikmalaya pada pembelajaran akuatik masih dalam kategori Mulai Berkembang (MB). Hal ini terlihat dari temuan di TK Laboratorium Percontohan UPI Kampus Tasikmalaya bahwa persentase perolehan kemampuan kognitif anak sebesar 44\%. Penelitian lanjutan diperlukan sebagai upaya untuk meningkatkan kemampuan kognitif anak usia dini dalam pembelajaran akuatik. Penerapan model pembelajaran dan strategi pengajaran dapat dilakukan agar perkembangan potensi anak dapat ditingkatkan.

\section{UCAPAN TERIMAKASIH}

Penelitian ini berlangsung karena dukungan berbagai pihak diantaranya TK Laboratorium Percontohan UPI Kampus Tasikmlaya. Selain itu, peneliti mengucapkan terima kasih kepada pemberi dana penelitian dari Universitas Pendidikan Indonesia Tahun Anggaran 2019 dengan Surat Keputusan Rektor Nomor 5493/UN40/KP/2019 Tanggal 28 Mei 2019 sehingga penelitian ini dapat diselesaikan dan berjalan dengan baik. 


\section{DAFTAR PUSTAKA}

Alaniz, M. L., Rosenberg, S. S., Beard, N. R., \& Rosario, E. R. (2017). The Effectiveness of Aquatic Group Therapy for Improving Water Safety and Social Interactions in Children with Autism Spectrum Disorder: A Pilot Program. Journal of Autism and Developmental Disorders, 47(12), 4006-4017.

Barnett, L. A., \& Kleiber, D. A. (1982). Concomitants of Playfulness in Early Childhood: Cognitive Abilities and Gender. Journal of Genetic Psychology, 141(1), 115-127.

Conatser, P., James, E., \& Karabulut, U. (2018). Adapted Aquatics for Children with Severe Motor Impairments. International Journal of Aquatic Research and Education, 10(3), 5.

Faber, R. (2017). Dance and early childhood cognition: The Isadora effect. Arts Education Policy Review, 118(3), 172-182. https://doi.org/10.1080/10632913.2016.1245166.

Geldard, K. \& Geldard, D. (2012). Konseling Anak-Anak. Jakarta: Indeks.

Hafina, A., Nur, L., \& Rusmana, N. (2019). Aquatic learning approach for improving early childhood basic attitude. Jurnal Pendidikan Jasmani dan Olahraga, 4(1), 86-91.

Hafina, A., Nur, L., \& Rusman, N. (2019). Basic Attitude Ability of Early Childhood in Aquatic Learning. In 2nd International Conference on Educational Sciences (ICES 2018). Atlantis Press. https://doi.org/https://doi.org/10.2991/ices-18.2019.8

Hasanah, U. (2016). Pengembangan Kemampuan Fisik Motorik Melalui Permainan Tradisional bagi Anak Usia Dini. Jurnal Pendidikan Anak, 5(1), 717-733.

Hidayat, S., \& Nur, L. (2018). Nilai Karakter, Berpikir Kritis dan Psikomotorik Anak Usia Dini. Jurnal Ilmiah VISI PGTK PAUD dan DIKMAS, 13(1), 29-35.

Hurlock, E. B. (1980). Psikologi Perkembangan. Jakarta: Erlangga.

Ibda, F. (2015). Perkembangan Kognitif: Teori Jean Piaget. Jurnal Intelektualita, 3(1), 27-38.

Langendorfer, S. J., \& Lawrence, B. D. (1995). Aquatic Readinesss. Developing Water Competence in Young Children. Canada: Human Kinetics Publisher Inc.

Langendorfer, S. J. (2009). Water Learning: Improving Mental, Physical, and Social Skills through Water Activities. International Journal of Aquatic Research \& Education, 3(1), 101-104.

Malik, A. A. (2013). "Ular Tangga Olahraga" Media Permainan Edukatif untuk Olahraga dengan Menggunakan Sistem Sirkuit Training bagi Siswa Kelas X SMA Negeri Ajibarang Tahun 2013. ACTIVE: Journal of Physical Education, Sport, Health and Recreations, 2(10), 630-636.

Nur, L., Mulyana, E.H., \& Perdana, M.A. (2017). Permainan Bola Kecil untuk Meningkatkan Keterampilan Motorik Kasar Anak Usia Dini pada Kelompok B di TK Pertiwi DWP Kota Tasikmalaya. Jurnal PAUD AGAPEDIA, 1(1), 53-65.

Nur, L., Halimah, M., \& Nurzaman, I. (2017). Permainan Tradisional Kaulinan Barudak untuk Mengembangkan Sikap Empati dan Pola Gerak Dasar Anak Usia Dini. Jurnal PAUD AGAPEDIA, 1(2), 170-180.

Nur, L., dkk. (2019). Basic Motor Ability: Aquatic Learning for Early Childhood. Journal of Physical Education, Sport, Health and Recreation, 8(2), 51-54.

Nurihsan, A. J. \& Agustin, M. (2011). Dinamika Perkembangan Anak dan Remaja. Bandung: Refika Aditama.

Pan, Chen-Yu. (2010). Effects of water exercise swimming program on aquatic skills and social behaviors in children with autism spectrum disorders. Autism, 14(1), 9-28.

Rahma, D. (2017). Penggunaan Alat Permainan Edukatif (APE) untuk Mendukung Perkembangan Anak Usia 5-6 Tahun di PAUD Al-Fikri. Jurnal Pendidikan dan Pembelajaran, 6(10), 1-10. 
Kemampuan Kognitif Anak Usia Dini Dalam Pembelajaran Akuatik

(Anne Hafina, Lutfi Nur, Nandang Rusmana)

Rahman, U. (2009). Karakteristik Perkembangan Anak Usia Dini. Jurnal Lentera Pendidikan, 12(1), 46-57.

Rakhmat, C. Budiman, N.; \& Herawati, N. I. (2008). Psikologi Pendidikan. Bandung: UPI Press.

Respati, R., Nur, L., \& Rahman, T. (2017). Gerak dan Lagu Sebagai Model Stimulasi Pengembangan Kecerdasan Kinestetik Anak Usia Dini. Jurnal Pendidikan Usia Dini, 12 (2), 321-330.

Rindaningsih, Ida. (2012). Pengembangan Model Manajemen Strategik Berbasis (Beyond Center and Circle Time) BBCT pada PAUD. Pedagogia. 1 (2), 213-223.

Rocha, H. A., Marinho, D. A., Garrido, N. D., Morgado, L. S., \& Costa, A. M. (2018). The acquisition of aquatic skills in preschool children: Deep versus shallow water swimming lessons. Motricidade, 14(1), 66-72.

Rochmah, L. I. (2012). Model Pembelajaran Outbound untuk Anak Usia Dini. Pedagogia, 1(2), 173188.

Santrock, J. W. (2007). Perkembangan Anak. Jakarta: Erlangga.

Sari, M. (2014). Peningkatan Kecerdasan Kinestetik Melalui kegiatan Bermain Air. Jurnal Pendidikan Anak Usia Dini, 8(1), 373-382.

Sismadiyanto. (2006). Diktat Akuatik II. Yogyakarta: Fakultas Ilmu Keolahragaan UNY.

Sujiono, Y. N. (2009). Konsep Dasar Pendidikan Anak Usia Dini. Jakarta: Indeks.

Susanto, E. (2009). Pembelajaran Akuatik Bagi Siswa Prasekolah. Cakrawala Pendidikan, XXVIII (3), 282-295.

Susanto, E. (2012). Model Pembelajaran Akuatik Siswa Prasekolah. Journal of Physical Education and Sports, 1(1), 37-47.

Susanto, E. (2014). Pembelajaran Akuatik Prasekolah: Mengenalkan Olahraga Air Sejak Dini. Yogyakarta: UNY Press.

Susilowati, E. (2014). Kematangan Emosi dengan Penyesuaian Sosial pada Siswa Akselerasi Tingkat SMP. Jurnal Online Psikologi. 1(1), 101-113.

Van de Waal, D. \& Henriette, A. (1993). Environmental Factors Influencing Growth and Pubertal Development Environmental Factors Influencing Growth and Pubertal Development. Amsterdam: Department of Pediatrics, Free University Hospital.

Yusuf, S. (2012). Psikologi Perkembangan Anak dan Remaja. Bandung: Remaja Rosdakarya 